DOI: $10.33067 /$ SE.1.2019.02

Fan Hornát ${ }^{\star}$

\title{
Transatlantic “Othering”: European External Action Identity and the Trump Administration
}

\begin{abstract}
Foreign policy is not only a reaction to the world as it is, but it also attempts to build a world as it should be. The European Union, being an actor on the international scene, grounds its external action in conceptions of the necessity of multilateralism and in building postmodern (postWestphalian) notions ofstate sovereignty. These elements are an inherent part of the Union's "foreign policy/identity nexus". The identity is reinforced by significant "Others", who do not share the EU's view of the ideal world order. The Donald Trump administration's reluctance and even repudiation of multilateral solutions is a challenge for the operationalization of the EU's "foreign policy/identity nexus" and thus the US is currently in the position of the Union's constitutive "Other". However, while we would expect that this development would reinforce the EU's external action identity, the Trump presidency has at the same time empowered antiglobalist and sovereigntist forces in Europe, which will drive wedges into EU foreign policy and cause further incoherence, especially along the new/ old member state divide.
\end{abstract}

Key words: Transatlantic Relations, Sovereignty, Multilateralism, Othering, EU External Action, Donald Trump

\section{Introduction: the Inevitability of Identity in Foreign Politics}

The formulation of foreign policies of states - and for that matter any other actor that conducts foreign policy - are on the one hand grounded in specific ideational narratives and in the states' material interests on the

^ Jan Hornát - Institute of International Relations, Prague, e-mail: janhornat@ seznam.cz, ORCID: 0000-0001-5336-6733. 
other hand. Whereas material interests presuppose a state to make decisions and adopt postures that are of immediate or medium-term benefit to its economy, security and its constituency in general, ideals and visions of how the international system should be constructed play a significant part in how states and other international actors shape their foreign policies. Foreign policy reacts to the world as it is, but also attempts to build a world as it should be (of course, the visions of potential worlds differ for every actor). Therefore, all international actors - most notably the United States, ${ }^{1}$ but also China ${ }^{2}$ - undergird their foreign policies with meta-narratives that help explain and give meaning to their conduct on the international scene. Needless to say, these two pillars - material and ideational - of foreign policy may thus often find themselves in conflict with each other.

Of course, the role of ideas and non-material interests in foreign policy has been widely described by constructivists and post-structuralists elsewhere, but it is necessary to remind ourselves of such perspectives when we speak of EU external action. ${ }^{3}$ Already in 1973 in the Copenhagen "Documenton European Identity" the member states declared that in their common policy in relation to third countries they wish to be recognized by the international society as a "single entity" - in other words, the aspiration to conduct a common foreign policy was clearly recognized. ${ }^{4}$ Doubtlessly, the EU of today aspires to be a foreign policy actor in its own right and therefore it needs to operate with ideals and narratives that help construct its interest and thereby justify its foreign policy.

In short, the EU needs its own foreign policy identity. The more difficult question is how toshape an identity "from scratch"? Pundits have in the recent and less recent past pondered the role of an integrated Europe on the international scene and have framed various labels for it - calling it "civilian power" Europe, "normative power" Europe, "legitimizing

1 See: H. Nau, At Home Abroad: Identity and Power in American Foreign Policy, Cornell University Press, Ithaca 2002 or T. Smith, America's Mission: The United States and the Worldwide Struggle for Democracy - Expanded Edition, Princeton University Press, Princeton 2012.

2 G. Chan, Capturing China's International Identity: Social Evolution and Its Missing Links, “The Chinese Journal of International Politics”, no. 7(2)/2014, pp. 261-281.

${ }^{3}$ See: among others, A. Wendt, Social Theory of International Politics, Cambridge University Press, Cambridge 1999 or The Culture of National Security: Norms and Identity in World Politics, ed. P.J. Katzenstein, Columbia University Press, New York 1996.

${ }^{4}$ Bulletin of the European Communities. December 1973, No. 12, Luxembourg: Office for official publications of the European Communities. "Declaration on European Identity", pp. 118-122. 
power" Europe etc. ${ }^{5}$ Still, the EU is looking for its proper role in global affairs and attempting to consolidate its actorness, for example, via the establishment of the European External Action Service (EEAS) and the formulation of ambitious strategies. ${ }^{6}$

The aim of this essay is to reflect upon the European Union's foreign policy identity in the context of US President Donald Trump's administration. The initial premise for this reflection is the assumption that the Trump administration's foreign policy so far seems too disruptive for the EU's worldview and therefore the US will once again play the constitutive "Other" for European external action. At the same time, however, US foreign policy under the Trump administration may further drive wedges into the EU's Common Foreign and Security Policy (CFSP) by reinforcing and empowering sovereigntist forces within the Union.

\section{Formation and Operation of EU Foreign Policy Identity}

Especially in an entity such as the EU, which is composed of a number of individual components with differing conceptions of what the normative pillars of EU external action should be, identity formation is a complex process of deliberation and distillation from member states' own identities. These domestic political identities "form the starting point for our understanding of the influence of identity on European foreign policy" and provide raw "identity material". ${ }^{7}$

The "identity material" is hence molded into a collective identity, which "never determines foreign policy" but "merely delineates the realm of conceivable policy options" and eliminates certain "policy options from the menu of conceivable options". ${ }^{8}$ This collective identity is thence $o p$ erationalized in the process of making foreign policy at the EU level - for example in the EEAS. Not necessarily an actor of EU foreign policy, the EEAS is without a doubt an instrument of EU foreign policy and as such

5 F. Duchêne, The European Community and the Uncertainties of Interdependence, in: Nation Writ Large: Foreign Policy Problems Before the European Communities, eds. M. Kohnstamm, W. Hager, Macmillan, London 1973; I. Manners, Normative Power Europe: A Contradiction in Terms?, "Journal of Common Market Studies", no. 40(2)/2002, pp. 235-258; A. Persson, The EU and the Israeli-Palestinian Conflict 1971-2013: In Pursuit of a Fust Peace, Lexington Books, Lanham 2015.

${ }^{6}$ Shared Vision, Common Action: A Stronger Europe, A Global Strategy for the European Union's Foreign and Security Policy, June 2016, https://eeas.europa.eu/archives/ docs/top_stories/pdf/eugs_review_web.pdf.

7 K. Hebel, T. Lenz, The identity/policy nexus in European foreign policy, "Journal of European Public Policy", no. 23(4)/2016, p. 477.

${ }^{8}$ Ibidem. 
demonstrates the many processes that contribute to the formation of EU positions and identity. ${ }^{9}$

Balfour, Carta and Raik identify three major dynamics that lead to the formation of EU foreign policy. The first dynamic can be identified as "downloading", which is a process of adaptation of national policies and organizations in response to requirements at the EU level. The process would suggest that to some extent, foreign-policy making is a top-down process in which agendas are increasingly set in Brussels and member states increasingly transfer power to institutions such as the EEAS. Still, the process functions also in the other direction through "uploading". This concept sees the member states as realist actors who aim to use the EU in an instrumental fashion to further their national interests. They thereby perceive the EEAS, for example, as a vehicle to introduce certain agendas or priorities into EU foreign policy. Lastly, we can also observe an ongoing process of (elite) socialization or "crossloading", whereby states because of close and frequent diplomatic interaction in common institutions incrementally converge in what they see as their national interests. ${ }^{10}$ National interests thus become collective interests. Of course, all three dynamics have their merits and operate simultaneously to form the end product - EU foreign policy.

The internal context, however, is only one part of the equation of theformation of the "identity/foreign policy nexus". ${ }^{11}$ The external context - i.e. the identification of significant "Others" - is a key component of the process.

\section{The United States as the "Other" for the European Union}

Identity of the "Self" (be it an individual or an entire nation) is constructed inter alia with the help of juxtaposing the conduct and perceptions of various significant "Others" to oneself. ${ }^{12}$ As Campbell asserts, "Inescapable as it is, identity - whether personal or collective - is not

9 R. Balfour, Change or Continuity: A Decade of Evolution of EU Foreign Policy and the Creation of the European External Action Service, in: The European External Action Service and National Foreign Ministries: Convergence or Divergence?, eds. R. Balfour, C. Carta, K. Raik, Ashgate, Farnham 2015.

10 R. Balfour, C. Carta, K. Raik, Introduction, in:The European External Action Service and National Foreign Ministries: Convergence or Divergence?, ed. R. Balfour, Ashgate, Farnham 2015, pp. 6-7.

11 K. Hebel, T. Lenz, op. cit.

12 See: I.B. Neumann, Uses of the other: "The East" in European identity formation, University of Minnesota Press, Minneapolis MN 1999. 
fixed by nature, given by God, or planned by intentional behaviour. Rather, identity is constituted in relation to difference" (emphasis added). ${ }^{13}$ Analogically to the constitution of self-identity, "otherness" and difference are also shaped as a matter of perception and interpretation - i.e. they are not "God given". In this sense, as foreign policy is a means through which a state (a nation) directly engages with "Others", identity is deemed to be in part shaped by foreign policy which in turn reproduces and potentially reshapes identity. ${ }^{14}$

Self-identity is thus a factor that determines an actor's "preferences which ultimately result in actions the [actor] will choose to exercise." As Serena Simoni describes: "In essence, if a state identifies itself as a 'great power', it will have a different set of preferences or interests than one which identifies itself as a middle power. These types of considerations enable us to understand why the US and Europe seem to be headed in different directions. The Atlantic partners simply have different preferences due to self-defined identities within the larger international and transatlantic context. It is the social construction of their identities that determines diverging interests [...]" ${ }^{15}$

As a consequence, even a partner or an ally can become - to some extent - an "Other". The "Other" may not pose a threat to the physical or ontological security of the "Self", yet it may pose a threat for the implementation of a particular worldview or for the manifestation of selfidentity. In other words, the "Other" may hinder the creation of a world as it should be according to the "Self". This is the reason why scholars have been observing that the United States, in fact, is in many instances an "Other" for the EU and particularly for its foreign policy.

Diez distinguishes between four general modes of relationship between the "Self" and the "Other" that help construct identities of actors. First, the "Other" could be depicted as an "existential threat", whereby the relationship is securitized; second, the "Other" is considered "inferior" or less civilized from an orientalist perspective; third, the "Other" is represented as "violating universal principles" and last, the "other" is simply viewed as "different", but without passing value judgments.

13 D. Campbell, Writing Security: United States Foreign Policy and the Politics of Identity, University of Minnesota Press, Minneapolis MN 1998), p. 9.

14 See: D.J. Der, M. Shapiro, International/intertextual relations: postmodern readings of world politics, Lexington Books, Lexington MD 1989; A. Bukh, Fapan's National Identity and Foreign Policy, Routledge, New York NY 2010.

15 S. Simoni, Transatlantic Relations: A Theoretical framework, in: The Future of Transatlantic Relations: Perceptions, Policy and Practice, eds. A.M. Dorman, J.P. Kaufman, Stanford University Press, Stanford CA 2010, p. 30. 
It is primarily the third mode of relationship that the EU maintains with the US. ${ }^{16}$

The EU believes to stand for multilateralism, international cooperation, diplomacy, law-based international order and a post-modern conceptions of state sovereignty, while - in the eyes of Europeans - the US violates these principles when they stand in the way of the its national interest. To some extent, the EU's self-image of an ardent supporter of benign multilateralism and universal principles may be wishful-thinking, but the perception of the US as a power that often resorts to unilateralism and disrespects international law is a key factor in shaping the Union's identity and the envisaged role it believes to be playing in the international arena. The EU even tends to place itself as a check on American power - a position with which the US understandably does not feel comfortable. ${ }^{17}$

Moreover, the relationship of the EU's role on the international scene vis-à-vis the US is depicted as the relationship of "vanguard" and "laggard". The EU sees itself as playingthe leading role in political issues with a global reach and of universal value - such as environmental issues and international criminal justice. As Scheipers and Sicurelli note, " $[t]$ he vanguard-laggard configuration epitomizes the basic structure of 'othering' from which the other aspects of identity construction emerge and derive their significance" ${ }^{18}$ Also, the EU emphasizes that the means that it utilizes in achieving these objectives are "superior to thoseof the US, because the EU restricts itself to non-military, diplomatic and multilateral measures". ${ }^{19}$

Despite the observation that the process of "othering" works in both directions within the Transatlantic relationship, it is necessary to provide more nuance to the analysis. The process of depicting the US as the "Other" by the EU tends to be more intense when Republican administrations are in the White House, while during Democratic administrations - whose conceptions of the international system are more in line with those of the EU in recent years - the process seems less profound.

16 T. Diez, Constructing the Self and Changing Others: Reconsidering 'Normative Power Europe', “Millennium: Journal of International Studies”, no. 33(3)/2005, pp. 615-636.

17 See: T.G. Ash, The Peril of Too Much Power, "New York Times", 9 April 2002, https://www.nytimes.com/2002/04/09/opinion/the-peril-of-too-much-power.html (25.09.2018).

18 S. Scheipers, D. Sicurelli, Normative Power Europe: A Credible Utopia?, "Journal of Common Market Studies", no. 45(2)/2007, p. 453.

19 Ibidem. 


\section{The Foreign Policy Postures of the Trump Administration}

Of the issues that have led to Transatlantic rifts since the end of the Cold War, the most divisive are those that concern the concept of multilateralism. While the Europeans - in an interpretation that is perhaps too generalizing - believe that they live in a postmodern world where hard power and realpolitik are giving way to a law-based international order in which problems and incidents are solved through multilateral mechanisms, the Americans do not accept this thesis and continue to live in a world of balancing and hard power, using multilateral mechanism selectively only to further their national interests. ${ }^{20}$

The Europeans have to some extent accepted a post-Westphalian conception of sovereignty, because the traditional Westphalian understanding of state sovereignty has led to endemic wars on the continent, and thereby they surrender portions of their national decision-making competencies to the EU for the sake of systemic stability in Europe. As a consequence, any form of multilateralism (economic, security, environmental etc.) on the global stage is supported by the Europeans and arguably forms one of the core tenets of its foreign policy identity - without supporting multilateral solutions on the global scene, the EU would essentially deny itself and the project of European integration. The Americans, however, do not always share European enthusiasm - in fact, the US is often in opposition to European-led multilateral projects.

One of the notorious case studies is the International Criminal Court (ICC). The Rome statute establishing the Court and its jurisdiction was formed in 1998 and entered into force in 2002, but without the support of either the Democratic Clinton administration or the Republican Bush administration. Whereas the EU made the support and ratification of the ICC statute mandatory for its members, the US does not accept its jurisdiction. ${ }^{21}$ Other cases include climate change (US withdrawal from the Kyoto Protocol and the more recent Paris Climate Change Agreement), maritime law (United Nations Convention on the Law of the Seas) and more normative international agreements such as International Labour Organization conventions or the International Covenant on Economic, Social and Cultural Rights.

The Democratic Obama administration - partly as a reaction to the Bush administration's internationally denounced unilateralism - adopted an approach to multilateralism that was more sympathetic to the Europe-

20 R. Kagan, Power and Weakness, "Policy Review”, no. 113/2002, pp. 3-28.

21 Council Common Position 2003/444/CFSP, 16 June 2003 (OJ L 150/67). 
ans. ${ }^{22}$ Yet, perhaps Obama's too overt inclination toward multilateralism gave Donald Trump the ammunition to win the presidency, as among his main campaign topics were: the multilateral trade agreement with the EU and Asia (TTIP and TPP), multilateral diplomatic agreement with Iran (JCPOA), Paris Climate Change Accord (COP21) - all of which have been initiated and supported by the Obama administration. Indeed, in his first foreign policy speech during the presidential campaign, Donald Trump condemned multilateralism in general and clearly outlined his policy in this realm: "We will no longer surrender this country or its people to the false song of globalism. The nation-state remains the true foundation for happiness and harmony. I am skeptical of international unions that tie us up and bring America down and will never enter [...] And under my administration, we will never enter America into any agreement that reduces our ability to control our own affairs". ${ }^{23}$

As president, Donald Trump fulfilled the promise to his voters and withdrew from all the above-mentioned agreements and, echoing Ronald Reagan, addressed the $73^{\text {rd }}$ session of United Nations General Assembly in September 2018 asserting that: "America will always choose independence and cooperation over global governance, control, and domination [...] We will never surrender America's sovereignty to an unelected, unaccountable bureaucracy [...] America is governed by Americans. We reject the ideology of globalism, and we embrace the doctrine of patriotism. Around the world, responsible nations must defend against threats to sovereignty not just from global governance, but also from other, new forms of coercion and domination". ${ }^{24}$

The Trump administration has been critical of other concepts that constitute key tenets of the EU foreign policy identity - namely the promotion of democracy and support for human rights. A number of scholars argue that Donald Trump's positions on foreign affairs largely reflect the so-called "Jacksonian" tradition in US foreign policy. ${ }^{25}$ The Jacksonians are deemed

22 R. Gowan, B. Jones, Barack Obama as Quiet International Reformer, Brookings Institution, September 21, 2009, https://www.brookings.edu/opinions/barack-obamaas-quiet-international-reformer/ (27.09.2018).

23 The New York Times, Transcript: Donald Trump's Foreign Policy Speech, April 27, 2016, https:/www.nytimes.com/2016/04/28/us/politics/transcript-trump-foreignpolicy.html (27.09.2018).

${ }_{24}$ POLITICO, Full text: Trump's 2018 UN speech transcript, September 25, 2018, https://www.politico.com/story/2018/09/25/trump-un-speech-2018-full-text-transcript-840043 (27.09.2018).

${ }_{25}$ Walter Russell Mead described four traditions in US foreign policy (Jeffersonian, Hamiltonian, Wilsonian and Jacksonian) in his book $A$ Special Providence: American Foreign Policy and How It Changed the World, Routledge, New York 2002. 
to be "sovereigntists who assert that the prime goal of U.S. domestic and foreign policy must be the physical security and economic prosperity" and therefore are "skeptical of domestic or foreign 'do-gooding". ${ }^{26}$

In this sense, in the first major foreign policy speech as a candidate, Trump claimed that America's foreign policy problems are largely caused by the "dangerous idea that we could make Western democracies out of countries that had no experience or interest in becoming a Western democracy". ${ }^{27} \mathrm{He}$ later reiterated these words as president-elect in December 2016, promising that the US is "going to stop trying to build new nations in far off lands". ${ }^{28}$ Trump's vision for the US in the global support for liberal democratic politics and human rights was a more passive kind of engagement - through providing an "example" for other nations and peoples to follow. This notion was clearly articulated in his Inaugural speech, where he mentioned that "We do not seek to impose our way of life on anyone, but rather to let it shine as an example for everyone to follow". ${ }^{29}$ In line with Trump's perspective, the administration's first Secretary of State, Rex Tillerson, in his first speech to State Department employees, affirmed the position that promoting American values "creates obstacles" to pursuing US national security and economic interests. ${ }^{30}$

From the above we can see that there is significant space for the EU to engage in the "Othering" of the US. Against this backdrop the EU can reaffirm the core tenets of its identity and the role it wishes and believes to be playing in international affairs. The following section will determine this claim in more detail.

\section{The EU Taking the Place of the US?}

The generalizing narrative in EU discourse is that the US, under President Donald Trump, will definitely abandon the position of architect and

26 D.S. Hamilton, Trump's Facksonian Foreign Policy and its Implications for European Security, “The Swedish Institute of International Affairs”, 2017.

27 The New York Times, Transcript: Donald Trump's..., op. cit.

28 In his own words: Donald Trump in Hershey, Reading Eagle, December 16, 2016, http://www.readingeagle.com/news/article/in-his-own-words-donald-trump-in-hershey (27.09.2018).

29 Remarks of President Donald F. Trump - As Prepared For Delivery, Inaugural Address, January 20, 2017, Washington, D.C., https://www.whitehouse.gov/briefingsstatements/the-inaugural-address/ (24.07.2018).

30 Secretary of State Rex Tillerson addresses State Department employees, May 3, 2017, https://statedept.brightcovegallery.com/detail/videos/remarks-events/video/ 5420267717001/secretary-of-state-rex-tillerson-addresses-state-department-employees (24.07.2018). 
guarantor of the "liberal world order". If the post-Cold War order rests on the pillars of international law-based multilateral cooperation, free trade and human rights of the individual that are best guaranteed by liberal democracy, then the US is quite overt in demonstrating that these principles and their promotion globally is no longer in its national interest. But leaving aside the many debates about the definitions, understandings and interpretations of what the "liberal world order" actually means, it seems that the EU aims to replace or substitute Washington in this role.

So it seems at least from the proclamations and postures of Western European politicians. In April 2018, French President Emmanuel Macron in a rare speech to the joint meeting of the US Congress defended the "liberal order" based on multilateralism, namely supporting the JCPOA, the Paris Climate Accord and calling on the US not to isolate itself and withdraw from the international scene: "We have to shape our common answers to the global threats that we are facing. The only option then is to strengthen our cooperation. We can build the 21 st century world order, based on a new breed of multilateralism. Based on a more effective, accountable, and results-oriented multilateralism. A strong multilateralism.

This requires more than ever the United States' involvement, as your role was decisive for creating and safeguarding today's free world. The United States invented this multilateralism. You are the one now who has to help to preserve and reinvent it.

This strong multilateralism will not outshine our national cultures and national identities. It is exactly the other way around". ${ }^{31}$

German Chancellor Angela Merkel allegedly decided to run for a fourth term because of Donald Trump's election. According to the memoir of Ben Rhodes, Obama's deputy National Security Advisor, Merkel explained to Obama that she felt more obliged to run for another term "to defend the liberal international order". Rhodes also noted that when the two parted for the final time, Merkel had "a single tear in her" eye and Obama noted: "She's all alone". ${ }^{32}$ German foreign minister, Heiko Maas, a social democrat, went even further in stating that the EU should cope with the fact that the US is incrementally withdrawing from its position as a guarantor of the world order. As a consequence, the Europeans must

31 Embassy of France in Washington D.C., French President Emmanuel Macron addresses U.S. Congress, Washington, D.C., April 25, 2018, https://franceintheus.org/ spip.php?article8612 (27.09.2018).

32 P. Baker, How Trump's Election Shook Obama: 'What if We Were Wrong?', “The New York Times", May 30, 2018, https:/www.nytimes.com/2018/05/30/us/politics/ obama-reaction-trump-election-benjamin-rhodes.html (27.09.2018). 
join forces in upholding the international system and strive for a multilateral alliance - "a network of partners who, like us, are committed to sticking to the rules and to fair competition". Maas, implicitly discussing EU identity, said that, "The European Union must become a cornerstone of the international order, a partner for all those who are committed to it. She is predestined for this, because compromise and balance lie in her DNA". ${ }^{33}$ Similar positions were echoed by other European politicians, including, for example, Belgian Prime Minister Charles Michel $^{34}$ and Polish President Andrzej Duda, who was more cautious, explaining that multilateralism must be based on a "sovereign equality of states": "If we want to be the advocates of multilateralism, and the UN is, after all, its source, we must bear this principle [sovereign equality of states] in mind. In other words, not everyone who claims to be a proponent of multilateralism thinks of it in terms of the equality of states. One can say that there is a negative multilateralism, which boils down to the concert of powers, a division into spheres of influence and the conviction that the fate of others can be decided without their participation. Europe and Poland were often victims of this kind of multilateralism [...]"35.

The narrative of Europe being the "last hope" of a liberal international order and the driving force of multilateralism is also adopted and reinforced by scholars and experts. The number of articles and policy papers regarding the EU's foreign policy role in the context of the Trump administration published by academics, research institutions and think-tanks is high - just to name a few, Foreign Affairs has published a piece titled "Germany Can Protect the Liberal Order", the European Council on Foreign Relations issued a policy brief asking "Can Europe save the world order?" and Carnegie Europe asked experts to reflect on the question "Can Europe Defend Multilateralism?". ${ }^{36}$ To some extent the EU is expected to take on

33 H. Maas, Making plans for a new world order, Handelsblatt, August 22, 2018, https://global.handelsblatt.com/opinion/making-plans-new-world-order-germanyus-trump-trans-atlantic-relations-heiko-maas-europe-956306 (27.09.2018).

34 La Province, Charles Michel plaide pour un ordremondial multilateral, September 27, 2018, http://www.laprovince.be/284584/article/2018-09-27/charles-michel-plaidepour-un-ordre-mondial-multilateral (28.09.2018).

35 Remarks by Andrzej Duda to the 73rd Session of the United Nations General Assembly, New York, 26 September, 2018, http://www.voltairenet.org/article203155. html (28.09.2018).

36 T. Benner, Germany Can Protect the Liberal Order: Damage Control After Trump's Election, "Foreign Affairs", November 16, 2016, https://www.foreignaffairs. com/articles/germany/2016-11-16/germany-can-protect-liberal-order; A. Dworkin, M. Leonard, Can Europe Save the World Order?, Policy Brief, European Council on Foreign Relations, May 24, 2018, https://www.ecfr.eu/publications/summary/can_europe_save_the_world_order; J. Dempsey, Fudy Asks: Can Europe Defend Multilateral- 
the role and at the same time it is imposing the role onto itself. However, this overlooks a key variable - there is a number of EU politicians in member states that more or less agree with Donald Trump's perspective on multilateralism and the maintenance of the liberal order and thus are likely to drive wedges into the common foreign policy of the EU.

\section{Conclusion: More Incoherence for EU External Action?}

For EU foreign policy identity, the Trump administration is an "Other". The EU does not share many aspects of the administration's conceptions of international affairs - especially its interpretation of sovereignty and law-based multilateralism. Juxtaposing itself to the current US foreign policy, the EU is consolidating the themes and visions it wishes to promote on the international scene. In fact, on the rhetorical level, the EU positions itself as the successor of the US in upholding a rules-based multilateral order. As the US adopts a less activist posture in human rights and democracy promotion, we are also likely to see the EU increasingly profiling its external action around these issues. Nonetheless, we are yet to witness whether action will meet the ambitious rhetoric.

At the same time, however, the Trump administration has vindicated and empowered anti-globalist and sovereigntist forces (not only) in Europe. The post-Westphalian conception of sovereignty that emerged in the 2000s and gained traction with norms such as the Responsibility to Protect (R2P) and which was advocated by European politicians including British Prime Minister Tony Blair, German Foreign Minister Joschka Fischer or EU High Representative for the Common Foreign and Security Policy Javier Solana, is backsliding into more "traditional" interpretations of sovereignty. ${ }^{37}$ With the increase of migration to Europe and the crisis of its management, especially the Eastern (or "New") EU member states have reverted to an understanding of sovereignty that is more in line with what Donald Trump

ism?, Carnegie Europe, May 17, 2018, http://carnegieeurope.eu/strategiceurope/76379 (27.09.2018).

37 J. Solana, Securing Peace in Europe, Speech from Munster November 12, 1998, https://www.nato.int/docu/speech/1998/s981112a.htm; J. Fischer, From Confederacy to Federation - Thoughts on the finality of European integration, Speech at the Humboldt University in Berlin, 12 May 2000, https://web.archive.org/web/20020502231325/http:// www.auswaertiges-amt.de/www/en/eu_politik/ausgabe_archiv?suche $=1 \&$ archiv_ $\mathrm{id}=1027 \&$ bereich_id=4\&type_id=3; T. Blair, Doctrine of International Community, Speech in Chicago, April 22, 1999, https:/www.globalpolicy.org/component/content/ article/154-general/26026.html (28.09.2018). 
advocates than with what Western (the "Old") EU states conceive. ${ }^{38}$ The US is therefore depicted as the "Other" more strongly in Western EU states than in the Eastern EU states. This will undoubtedly hinder consensus regarding the EU's role in world affairs and cause further incoherence - even despite the ongoing "othering" processes. As the role of Member states within EU agencies such as the EEAS is increasingand through informal lobbying and backing the capitals are trying to have influence over personnel decisions and in shaping the agendas, there is likely going to be more "uploading" rather than "downloading", which will lead to a diversification of preferences within EU external action and thus increased incoherence. ${ }^{39}$

\section{References}

Ash T.G., The Peril of Too Much Power, "New York Times”, 9 April 2002, https://www.nytimes.com/2002/04/09/opinion/the-peril-of-too-muchpower.html.

Baker P., How Trump's Election Shook Obama: 'What if We Were Wrong?', "The New York Times", May 30, 2018, https://www.nytimes.com/ 2018/05/30/us/politics/obama-reaction-trump-election-benjaminrhodes.html.

Benner T., Germany Can Protect the Liberal Order: Damage Control After Trump's Election, "Foreign Affairs", November 16, 2016, https://www. foreignaffairs.com/articles/germany/2016-11-16/germany-can-protectliberal-order.

Blair T., Doctrine of International Community, Speech in Chicago, April 22, 1999, https://www.globalpolicy.org/component/content/article/154general/26026.html.

Bukh A., Fapan's National Identity and Foreign Policy, Routledge, New York NY 2010, https://doi.org/10.4324/9780203883754.

Bulletin of the European Communities. December 1973, No 12. Luxembourg: Office for official publications of the European Communities. "Declaration on European Identity", pp. 118-122.

Campbell D., Writing Security: United States Foreign Policy and the Politics of Identity.

38 P. Gorondi, Hungary's Orban praises Trump's 'end of multilateralism', Associated Press, January 23, 2017, https://apnews.com/71de471223cc486cac44f6c70e448133 (28.09.2018).

39 Based on author's interviews with EEAS employees in September 2018. 
Chan G., Capturing China's International Identity: Social Evolution and Its Missing Links, "The Chinese Journal of International Politics", no. 7(2)/2014, pp. 261-281.

Charles Michel plaide pour un ordre mondial multilateral, La Province, September 27, 2018, http://www.laprovince.be/284584/article/2018-09-27/ charles-michel-plaide-pour-un-ordre-mondial-multilateral.

Council Common Position 2003/444/CFSP, 16 June 2003 (OJ L 150/67).

Dempsey J., Fudy Asks: Can Europe Defend Multilateralism?, "Carnegie Europe", May 17, 2018, http://carnegieeurope.eu/strategiceurope/76379.

Der Derian J., Shapiro M., International/intertextual relations: postmodern readings of world politics, Lexington Books, Lexington MD 1989).

Diez T., Constructing the Self and Changing Others: Reconsidering 'Normative Power Europe', "Millennium: Journal of International Studies”, no. 33(3)/2005, pp. 615-636.

Dworkin A., Leonard M., "Can Europe Save the World Order?", Policy Brief, European Council on Foreign Relations, May 24, 2018, https:// www. ecfr.eu/publications/summary/can_europe_save_the_world_order.

Embassy of France in Washington D.C., "French President Emmanuel Macron addresses U.S. Congress", Washington, D.C., April 25, 2018, https://franceintheus.org/spip.php?article8612.

Fischer J., From Confederacy to Federation - Thoughts on the finality of European integration, Speech at the Humboldt University in Berlin, 12 May 2000, https://web.archive.org/web/20020502231325/http://www.auswaertigesamt.de/www/en/eu_politik/ausgabe_archiv?suche $=1 \& a r c h i v \_$ $\mathrm{id}=1027 \&$ bereich_id=4\&type_id $=$.

Gorondi P., Hungary's Orban praises Trump's 'end of multilateralism, "Associated Press", January 23, 2017, https://apnews.com/71de471223cc486ca c44f6c70e448133.

Gowan R., Jones B., Barack Obama as Quiet International Reformer, Brookings Institution, September 21, 2009, https://www.brookings.edu/ opinions/barack-obama-as-quiet-international-reformer/.

Hamilton D.S., Trump's Facksonian Foreign Policy and its Implications for European Security, The Swedish Institute of International Affairs, 2017.

Hebel K., Lenz T., The identity/policy nexus in European foreign policy, "Journal of European Public Policy", no. 23(4)/2016, pp. 473-491.

Kagan R., Power and Weakness, "Policy Review", no. 113/2002, pp. 3-28.

Maas H., Making plans for a new world order, Handelsblatt, August 22, 2018, https://global.handelsblatt.com/opinion/making-plans-newworldorder-germany-us-trump-trans-atlantic-relations-heiko-maaseurope956306. 
Manners I., Normative Power Europe: A Contradiction in Terms?, "Journal of Common Market Studies", no. 40(2)/2002, pp. 235-258.

Mead W.R., A Special Providence: American Foreign Policy and How It Changed the World, Routledge, New York 2002.

Nation Writ Large: Foreign Policy Problems Before the European Communities, eds. M. Kohnstamm, W. Hager, Macmillan, London 1973.

Nau H., At Home Abroad: Identity and Power in American Foreign Policy, Cornell University Press, Ithaca 2002.

Neumann I.B., Uses of the other: "The East" in European identity formation, University of Minnesota Press, Minneapolis MN 1999.

Persson A., The EU and the Israeli-Palestinian Conflict 1971-2013: In Pursuit of a Fust Peace, Lexington Books, Lanham 2015.

POLITICO, Full text: Trump's 2018 UN speech transcript, September 25, 2018, https://www.politico.com/story/2018/09/25/trump-un-speech2018-full-text-transcript-840043.

Reading Eagle, In his own words: Donald Trump in Hershey, December 16, 2016, http://www.readingeagle.com/news/article/in-his-own-wordsdonald-trump-in-hershey.

Remarks by Andrzej Duda to the 73rd Session of the United Nations General Assembly, New York, 26 September, 2018, http://www.voltairenet. org/article203155.html.

Remarks of President Donald 7. Trump - As Prepared For Delivery, Inaugural Address, January 20, 2017, Washington, D.C., https://www.whitehouse. gov/briefi ngs-statements/the-inaugural-address/.

Scheipers S., Sicurelli D., Normative Power Europe: A Credible Utopia?, "Journal of Common Market Studies", no. 45(2)/2007, pp. 435-457.

Secretary of State Rex Tillerson addresses State Department employees, May 3, 2017, https://statedept.brightcovegallery.com/detail/videos/remarks-events/video/5420267717001/secretary-of-state-rex-tillersonaddresses-statedepartment-employees.

Shared Vision, Common Action: A Stronger Europe, A Global Strategy for the European Union's Foreign and Security Policy, June 2016, https://eeas. europa.eu/archives/docs/top_stories/pdf/eugs_review_web.pdf.

Smith T., America's Mission: The United States and the Worldwide Struggle for Democracy - Expanded Edition, Princeton University Press, Princeton 2012, https://doi.org/10.1515/9781400842025.

Solana J., Securing Peace in Europe, Speech from Munster November 12, 1998, https://www.nato.int/docu/speech/1998/s981112a.htm.

The Culture of National Security: Norms and Identity in World Politics, ed. P.J. Katzenstein, Columbia University Press, New York 1996. 
The European External Action Service and National Foreign Ministries: Convergence or Divergence?, eds. R. Balfour, C. Carta, K. Raik, Ashgate, Farnham 2015.

The Future of Transatlantic Relations: Perceptions, Policy and Practice, eds. A.M. Dorman, J.P. Kaufman, Stanford University Press, Stanford CA 2010.

The New York Times, Transcript: Donald Trump's Foreign Policy Speech, April 27, 2016. https://www.nytimes.com/2016/04/28/us/politics/transcript-trump-foreign-policy.html.

Wendt A., Social Theory of International Politics, Cambridge University Press, Cambridge 1999, https://doi.org/10.1017/CBO9780511612183. 